\title{
BEBERAPA PANDANGAN TENTANG GURU SEBAGAI PENDIDIK
}

\author{
Oleh: Bahaking Rama
}

\begin{abstract}
The Education very determines of development step of a nation. The Nation prioritizing of education sector development will become the nation progress and has high civilization. In the educational process consists of some factors determining. One of the factors is teacher. The teacher has right and obligation in order to run his duty as a teacher or educator. Relating with his obligation is as a teacher. The teacher is demanded to take responsibility for developing potential, grind down intelligence, and transfer knowledge and technology to the learners in order to sharpen the life of nation. While relating with his duty is as educator, the teacher is demanded to take responsibility for, besides to sharpen the learners mind, he also takes responsibility for pounding the learners' personality and morality or character.
\end{abstract}

KEYWORDS: Pendidikan, guru, pengajar, pendidik, kompetensi kepribadian, pedagogik, sosial, dan profesional.

PENDIDIKAN merupakan sarana yang sangat stategis dan ampuh dalam mengangkat harkat dan martabat bangsa. Dengan pendidikan, seseorang akan memiliki bekal pengetahuan untuk memasuki lapangan kerja. ${ }^{1}$ Pendidikan menjadikan seseorang berilmu pengetahuan. Dengan ilmu dan iman, seseorang akan terangkat derajatnya sebagaimana yang dijanjikan Allah swt. dalam Q.S. Al-Mujadalah (58): 11, yang artinya “... niscaya Allah akan meninggikan orang-orang yang beriman di antaramu dan orang-orang yang diberi ilmu pengetahuan beberapa derajat. Dan Allah maha mengetahui apa yang kamu kerjakan."2

Bangsa yang mengutamakan pendidikan akan melahirkan peradaban tinggi dan tidak gampang dijajah bangsa lain. Sebaliknya, bangsa yang tidak memperhatikan pendidikan, akan rawan terjadi kebiadaban dan gampang dijajah atau diperalat oleh bangsa lain. Dalam hubungan ini, Muhammad Athiyah Al-Abrasyi berpendapat bahwa sangat mustahil suatu bangsa bisa menjadi maju tanpa melakukan pemerataan dan peningkatan pendidikan-pengajaran. Ia sangat yakin, bahwa dengan memperhatikan pendidikan, maka suatu bangsa akan menjadi lebih maju dan berkualitas. $^{3}$ 
Selanjutnya, Abrasyi berpendapat bahwa bangsa dan negara yang tidak memperhatikan pembangunan bidang pendidikan akan berdampak kepada: mewabahnya berbagai penyakit, banyak orang miskin dan buta huruf, merajalelanya pengemis dan gelandangan, serta merebaknya penyimpangan moral dan kriminal.

Bagaimanakah gambaran suatu negara yang memperhatikan pendidikan? Jawabannya dapat dilihat atau diukur pada:

\section{Pemerintahnya Mempunyai Perhatian Serius dalam Meningkatkan Mutu dan Kesejahteraan Guru}

Kejayaan negara Islam di zaman klasik (abad 7-13 M.), karena pemerintahnya sangat memperhatikan mutu atau kualitas dan kesejahteraan guru. Khalifah Umar Bin Khattab, misalnya, menggaji setiap guru sebesar 63 gram emas perbulan dan menghargai karya tulis setiap guru dengan memberi emas seberat buku yang ditulisnya.

\section{Pendidikan Gratis}

Negara Mesir dalam revolusi pendidikannya di akhir abad $19 \mathrm{M}$. menggratiskan pendidikan dasar dan menengah. Pada tahun 1962, Jamal Abdel Nasser (presiden Mesir), menggratiskan pula biaya pendidikan pada mahasiswa di perguruan tinggi. Dengan perhatian serius pemerintah kepada bidang pendidikan, kini Mesir terhitung maju dan menjadi negara religius yang modern, sama modernnya dengan negara-negara maju lainnya. Tampaknya, pendidikan gratis menjadi atau sebagai prinsip optimalisasi pemerataan pendidikan pada semua lapisan masyarakat, tanpa membedakan status sosial, kaya-miskin semua berpendidikan.

\section{Kurikulum yang Aplikatif-Praktis}

Kurikulum di setiap jenjang pendidikan formal sangat memperhatikan keseimbangan ranah kognitif, afektif, dan psikomotorik. Dari kurikulum tersebut, proses pembelajaran dapat meningkatkan mutu dan kualitas sumber daya manusia peserta didik yang dapat mengekploitasi sumber daya alam secara profesional dan etis, dengan tujuan untuk sebesar-besarnya kemakmuran rakyat atau bangsa.

\section{Sarana-Prasarana dan Media-Teknologi Pembelajaran Cukup Tersedia}

Pemerintah yang mempunyai perhatian pada sektor pendidikan, tentu saja sarana-prasarana serta media dan teknologi pembelajaran yang layak, cukup tersedia untuk maksimalisasi proses pembelajaran bagi guru dan peserta didik. Artinya, tidak akan terdapat gedung sekolah rusak atau bocor serta tidak cukup fasilitas pembelajaran. 
Bangsa yang memperhatikan pendidikan berdampak pada: bangsa tersebut akan maju dan berkualitas moral dan kehidupan agamanya, ekonominya, kesehatannya, sosial budaya dan peradabannya, stabilitas keamanannya, dan yang lainnya. Artinya, bangsa tersebut tidak akan meninggalkan generasi yang lemah karena mereka dibekali pendidikan yang dapat menjadikan mereka kuat, baik fisik maupun mentalnya. ${ }^{4} \mathrm{Hal}$ ini sesuai firman Allah dalam Q.S. al-Nisa (4): 9, yang artinya: "Dan hendaklah takut kepada Allah, orang-orang yang seandainya meninggalkan di belakang mereka anak-anak yang lemah, yang mereka khawatir terhadap (kesejahteraan) mereka. Oleh sebab itu, hendaklah mereka bertakwa kepada Allah dan hendaklah mereka mengucapkan perkataan yang benar." 5

Dengan pendidikan, seseorang atau suatu bangsa akan memiliki keterampilan dan menguasai ilmu pengetahuan dan teknologi. Pekerjaan tanpa didukung ilmu dan keahlian atau keterampilan akan mendatangkan kehancuran. Hal ini sesuai hadis Nabi Muhammad saw. riwayat Imam Bukhari, yang maksudnya "jika suatu pekerjaan diserahkan kepada yang bukan ahlinya, atau tidak mempunyai pengetahuan tentang itu, tunggu saat kehancurannya."

Suatu negara cepat maju kalau bidang pendidikan diutamakan. Sebagai contoh dapat dilihat negara tetangga, Singapura dan Malaysia, betapa majunya kedua negara tersebut karena sangat memperhatikan pendidikan, bahkan menggratiskannya. Jangankan Singapura, Malaysia, apalagi Jepang, negara Vietnam pun yang baru berkembang dan sering bergolak sudah mengalami kemajuan yang sangat signifikan. Negara ini mempunyai prinsip dasar tentang pendidikan, yaitu: "tidak ada guru, tidak ada pendidikan; tidak ada pendidikan tidak akan meningkat ekonomi dan pengembangan kehidupan sosial yang mapan dan stabil. No teacher no education, no education no economic and social development."6

Salah satu faktor yang menentukan berhasil dan majunya pendidikan di suatu bangsa adalah guru atau pendidik. Oleh karena itu, tulisan ini diberi judul: "Beberapa Pandangan tentang Guru sebagai Pendidik." Dalam tulisan ini dibahas makna dan hakekat guru, pandangan tentang guru di era globalisasi, kemandirian guru, faktor determinan dalam pendidikan, serta pandangan tentang hak dan kewajiban guru. Tulisan ini bertujuan untuk mengemukakan beberapa pandangan tentang guru sebagai pendidik, dengan harapan semoga para pembaca lebih memahami dan menghayati betapa pentingnya keberadaan atau kedudukan guru di dalam suatu negara. 


\section{PANDANGAN TENTANG MAKNA DAN HAKEKAT GURU}

Apakah atau siapakah yang dimaksud guru? Jawabannya sebagai berikut. Di dalam Undang-undang RI Nomor: 14 Tahun 2005 tentang Guru dan Dosen ditetapkan bahwa guru adalah pendidik profesional dengan tugas utama mendidik, mengajar, membimbing, mengarahkan, melatih, menilai, dan mengevaluasi peserta didik pada pendidikan anak usia dini jalur pendidikan formal, pendidikan dasar, dan pendidikan menengah. ${ }^{7}$ Dalam pandangan masyarakat umum, guru adalah orang yang melaksanakan pendidikan di tempat-tempat tertentu, baik pada lembaga pendidikan formal, informal, maupun nonformal. ${ }^{8}$ Dalam kajian tulisan ini, yang dimaksud guru adalah orang yang diangkat secara resmi dengan surat keputusan oleh suatu lembaga atau yayasan sebagai pengajar dan pendidik pada lembaga pendidikan formal.

Zakiah Daradjat berpendapat bahwa tidak sembarang orang dapat menjadi guru. ${ }^{9}$ Pada hakekatnya, seorang guru sangat dipercaya oleh orang tua peserta didik untuk memikul sebagian tanggung jawab pendidikan anaknya kepada guru. Di berbagai negara, guru sangat dihormati oleh masyarakat karena dapat mengajar dan mendidik generasi pelanjut negara itu.

Siapapun tentu sependapat bahwa guru merupakan unsur utama dalam keseluruhan proses pendidikan. Saya memandang bahwa tanpa guru, pendidikan hanya akan menjadi pembicaraan yang omong kosong. Guru menjadi titik sentral dan awal dari semua pembangunan pendidikan dan pembangunan yang lebih luas dan menyeluruh. Prinsip inilah yang ditanamkan negara Jepang yang banyak diikuti negara lain sehingga cepat maju pembangunannnya, misalnya Singapura, Malaysia, Thailan, dan bahkan Vietnam sekalipun. Ketika Provinsi Hirosima dan Nagasaki di Jepang diluluh lanta bom atom pada perang dunia II (1945), Kaisar Jepang bertanya, "masih adakah guru yang hidup"? Ini berarti, betapa besar perhatian Kaisar Jepang terhadap pendidikan dan betapa besar peranan guru dalam pembangunan suatu bangsa.

Kini, setelah 62 tahun peristiwa perang duni II berlalu (seumur kemerdekaan Indonesia), dunia mengakui kemajuan Jepang dari berbagai bidang kehidupan. Ia maju dalam bidang ilmu pengetahuan dan teknologi, ekonomi, politik, sosial budaya, dan agama, serta pertahanan keamanan dan bidang lainnya. Artinya, tanpa guru yang berkualitas dan profesional, pendidikan tidak akan berhasil secara maksimal; karena tidak dapat meningkatkan sumber daya manusia berkualitas tinggi yang dapat mengeksploitasi sumber daya alam untuk kemakmuran umat manusia di dunia dan akhirat. 
Bagaimana di Indonesia negara tercinta ini? Dalam pengamatan penulis, sungguh disayangkan karena selama ini, guru ternyata belum mendapatkan posisi yang seharunya ditempati. Guru masih termarginalkan atau berada pada posisi peripheral atau terpinggirkan dalam kebijakan program pembangunan pendidikan. Tampak jelas bahwa penghargaan mayoritas masyarakat Indonesia terhadap guru masih rendah. Guru sejatinya mendapat perlakuan yang lebih terhormat dari berbagai pihak, karena guru merupakan agen pembaruan dan pendukung nilai-nilai budaya yang berkembang di masyarakat. Di dalam menjalankan tugasnya, guru senantiasa memotivasi peserta didiknya untuk mencari dan mencintai ilmu serta menganjurkan belajar tekun, menyimak dan mengamalkan ilmu yang dipahaminya. Meskipun tugas guru sangat mulia, tetapi masih terdapat sebagian masyarakat kurang paham dan menganggap tugas guru sebagai pekerjaan biasa dan kurang penting.

Walaupun demikian, kini patut disyukuri karena pemerintah sudah mempunyai perhatian terhadap pendidikan yang dimulai dengan perhatian terhadap peningkatan mutu dan kesejahteraan guru yang ditandai dengan lahirnya Undang-undnag RI Nomor: 14 Tahun 2005 tentang Guru dan Dosen. Tentu harapan besar dari para guru dan dosen, atau juga harapan dari masyarakat, semoga Undang-undang RI tersebut segera dapat diaplikasikan. Tanpa itu, pendidikan tidak akan sampai pada citacita pembukaan UUD 1945, yaitu mencerdaskan kehidupan bangsa, yang tentu saja melalui pengembangan sumber daya manusia.

\section{PANDANGAN TENTANG GURU DI ERA GLOBALISASI}

Di era globalisasi abad 21 ini, perkembangan zaman menuntut terjadinya pergeseran paradigma dalam proses pembelajaran. Misalnya, paradigma lama memandang bahwa pembelajaran penting, hanya dapat dilakukan melalui fasilitas pembelajaran formal. Sedangkan paradigma baru memandang bahwa orang dapat mempelajari sesuatu dari banyak sumber, kapan dan di mana saja tanpa melalui proses pembelajaran formal. Demikian juga paradigma lama dan paradigma baru lainnya. Perkembangan global yang terjadi dewasa ini, menjadi tantangan sekaligus peluang pada setiap guru dalam melaksanakan tugasnya. Bagaimana tantangan dan peluang itu? Dapat dilihat berikut ini.

\section{Tantangan}

Sebagaimana ungkapan di atas, di abad 21 atau millenium ketiga ini terjadi perkembangan global dengan segala karakteristiknya, terutama pesatnya perkembangan informasi, ilmu pengetahuan, dan teknologi. 
Itulah sebabnya, abad ini dikenal dengan era globalisasi. Menurut Muhamad Surya, ${ }^{10}$ era globalisasi ditandai dengan: pertama, ketergantungan antar bangsa di dunia; kedua, suasana kompetitif dalam segala bidang, terutama ekonomi; ketiga, kecenderungan makin homogen dalam pandangan dan perilaku; keempat, kecenderungan perubahan nilai dan etika sosial budaya. Dengan demikian, di era ini terjadi pergeseran paradigma atau cara berpikir dalam menghadapi berbagai fenomena.

Dalam menghadapi berbagai perubahan di era globalisasi diperlukan sumber daya manusia yang memiliki kualitas tinggi, agar mampu mengatasi berbagai tantangan yang timbul. Seorang guru dituntut kemampuannya untuk mengikuti atau mengejar kemajuan ilmu pengetahuan dan teknologi yang semakin cepat, agar tidak tertinggal dalam menjalankan tugas keguruan sebagai pengemban misi pembangunan. Guru juga dituntut kemampuannya mengatasi berbagai masalah yang timbul sebagai akibat pengaruh perubahan global. Di era ini, guru dituntut melakukan pembelajaran yang bersifat inovatif, ofensif, dan proaktif. Proses pembelajaran sejatinya bukan hanya dalam bentuk pemrosesan informasi, tetapi harus dikembangkan sedemikian rupa, sehingga dapat melahirkan sumber daya manusia kreatif yang adaptif terhadap tuntutan zaman yang semakin beragam. Lengkapkah fasilitas pembelajaran yang dapat menunjang tugas guru? Ketidaklengkapan fasilitas dan teknologi pembelajaran juga menjadi salah satu tantangan guru di era ini.

Di era ini, saya memandang, bahwa peserta didik sangat berpeluang mengembangkan kemampuannya mengikuti dan memahami kemajuan ilmu pengetahuan dan teknologi. Peserta didik dapat menyerap banyak informasi dari kecanggihan berbagai mass media, sehingga tidak menutup kemungkinan, peserta didik akan lebih maju pemahaman dan pengetahuannya terhadap suatu mata pelajaran dibandingkan gurunya. Itulah sebabnya sehingga tantangan yang dihadapi seorang guru di era ini, bukan saja dituntut menjalankan tugas sebagai pengajar secara profesional, tetapi juga dituntut memahami dan menguasai bahan pelajaran yang diajarkan dan ilmu-ilmu lain yang berhubungan dengan mata pelajaran yang diajarkan tersebut, sehingga guru semakin kaya materi ajar.

\section{Peluang}

Era globalisasi, yang ditandai pesatnya kemajuan ilmu pengetahuan dan teknologi serta bidang informasi dan komunikasi, memberi peluang kepada para guru atau pendidik untuk cepat memahami perkembangan ilmu pengetahuan dan teknologi tersebut. Artinya, semakin banyak informasi diperoleh, maka akan semakin terbuka peluang bagi guru untuk lebih 
meningkatkan tugasnya secara profesional. ${ }^{11}$ Ini berarti setiap guru dituntut kemampuannya mengoperasikan berbagai macam teknologi informasi.

Bekerja secara profesional harus didasari teori yang sudah teruji kevalidannya. ${ }^{12}$ Artinya, bekerja profesional harus berdasar pada teori, praktek, dan pengalaman. Dengan demikian, dipandang perlu untuk memberi dukungan sepenuhnya terhadap sertifikasi guru supaya guru dapat meningkatkan kualitas dan kompetensi mengajarnya untuk melaksanakan tugas secara profesional, sebagaimana yang dituntut oleh Undangundang Republik Indonesia Nomor: 14 Tahun 2005 tentang Guru dan Dosen.

\section{Permasalahan Guru}

Dari berbagai permasalahan guru dalam dunia pendidikan di Indonesia selama ini dapat dikemukakan antara lain.

1. kesulitan pemenuhan kebutuhan guru di sekolah-sekolah, seiring pertambahan jumlah siswa, baik secara kuantitas (tidak terpenuhi sejumlah fasilitas kebutuhan pembelajaran) maupun kualitas (tingkat kemampuan mengelola pembelajaran secara profesional).

2. jumlah kebutuhan guru berdasarkan perimbangan jenis kelamin, belum mendapat kajian sosiologis, psikologis, dan kajian lainnya.

3. penyebaran dan penempatan guru yang kadang kala tidak konsisten.

4. pemenuhan kebutuhan dan kesejahteraan guru masih sangat rendah. ${ }^{13}$

5. penugasan guru menangani mata pelajaran yang tidak sesuai latar belakang pendidikannya, dan banyak lagi masalah lainnya.

\section{KEMANDIRIAN GURU}

Muhamad Surya, ${ }^{14}$ menegaskan bahwa dalam keseluruhan kegiatan pendidikan, guru memegang posisi yang paling strategis. Menurutnya, dalam tingkat operasional, guru merupakan penentu keberhasilan pendidikan. Semua kebijakan pendidikan, bagaimanapun bagusnya, tidak akan memberikan hasil yang maksimal sepanjang guru tidak mendapat kesempatan mewujudkan otonomi pedagogisnya; yaitu kemandirian dalam memerankan fungsinya secara proporsional dan profesional. Kemandirian guru akan tercermin dalam perwujudan kinerjanya sebagai guru, baik ia sebagai pribadi atau individu, sebagai warga masyarakat, maupun sebagai seorang pegawai jika ia mempunyai kemampuan sebagai berikut.

1. Seorang guru memiliki daya juang yang tinggi (tangguh) serta memiliki keikhlasan dan kualitas iman-takwa yang mantap. ${ }^{15}$

2. Guru mampu mengikuti perkembangan global, kemajuan ilmu pengetahuan dan teknologi (supaya tidak ketinggalan informasi). 
3. Guru memiliki kompetensi keilmuan, yang meliputi antara lain: - Menguasai bidang studi/materi pelajaran dan ilmu yang berkaitan.

- Memahami sikap dan karakteristik serta perkembangan anak didik.

- Profesional dan kompetensi lainnya. ${ }^{16}$

4. Guru secara profesional melaksanakan tugasnya. Menurut Soedijarto, guru yang profesional, yaitu:

- dapat menyusun satuan pelajaran yang berarti bagi tercapainya tujuan pembelajaran

- dapat memilih teknik atau metode mengajar, bahan pelajaran, bentuk belajar, alat penilaian atau evaluasi kemajuan belajar, dan alat pelajaran secara tepat yang serasi dengan tujuan pendidikan yang hendak dicapai.

- mampu berkomunikasi dengan anak didik secara baik dan dapat membangkitkan motivasi belajar anak didik.

- dapat memahami arti setiap kegiatan belajar-mengajar dari setiap tahapan belajar.

- dapat mengelola proses belajar-mengajar secara dinamis dan kreatif.

- bersedia memberikan bantuan kependidikan kepada anak didik yang mengalami kesulitan belajar.

- dapat memberikan informasi pendidikan kepada orang tua anak didik.

- memahami dan sadar akan arti tugasnya sebagai kepentingan bangsa dan negara. ${ }^{17}$

5. Guru terpenuhi kesejahteraan lahir-batin atau material dan spiritual yang meliputi:

- gaji atau tunjangan berada pada tingkat kewajaran kebutuhan, adil, dan proporsional.

- rasa aman dalam melaksanakan tugas (kepastian dan perlindungan hukum).

- kondisi kerja yang kondusif (lingkungan dan fasilitas sekolah memadai)

- hubungan antar pribadi yang baik.

- kepastian dan jaminan jenjang karir masa depan.

6. Guru bersikap kreatif dan berwawasan masa depan (dapat melahirkan gagasan dan karya tulis ilmiah). ${ }^{18}$

Gambaran di atas memberi pandangan dan pemahaman, bahwa betapa pentingnya seorang guru dapat mewujudkan kemandiriannya sebagai pekerja profesional, yaitu pengajar dan pendidik. Ini berarti bahwa seorang guru harus memiliki bakat mengajar dan mendidik, sehingga dapat melaksanakan tugasnya berdasarkan teori-teori pembelajaran. 
Selain memiliki bakat mengajar, tentu saja seorang guru dituntut pula dapat memenuhi syarat-syarat formal. Menurut Zakiah Daradjat,19 seorang guru harus beriman dan bertakwa, mempunyai kompetensi, profesional, sehat jasmani-rohani, dan berkelakuan baik. Sedangkan menurut Muhammad Athiyah Al-Abrasyi, ${ }^{20}$ sifat-sifat yang harus dimiliki seorang guru adalah: sifat zuhud, mengajar karena mencari rida Allah, suci dan bersih, murah hati, tegas dan terhormat, bersikap dewasa dan kebapakan, mampu memahami karakteristik dan perkembangan peserta didik, kompeten dan profesional sebagai guru. Dengan demikian, dapat dipahami bahwa secara ideal, seorang guru haruslah manusia paripurna atau insan kamil, tetapi tentu saja tidak banyak orang yang seperti itu.

\section{FAKTOR-FAKTOR DETERMINAN DALAM PENDIDIKAN}

Ada beberapa faktor yang sangat berperan dan menentukan dalam pendidikan. Tentu setiap aktivitas dalam proses pendidikan berusaha mencapai tujuan pendidikan yang diinginkan. Di dalam Undang-undang RI Nomor: 20 Tahun 2003 tentang Sistem Pendidikan Nasional ditetapkan tujuan pendidikan nasional sebagai berikut, “. . . berkembangnya potensi peserta didik agar menjadi manusia yang beriman dan bertakwa kepada Tuhan Yang Maha Esa, berakhlak mulia, sehat, berilmu, cakap, kreatif, mandiri, dan menjadi warga negara yang demokratis serta bertanggung jawab." 21

Di dalam mengelola pendidikan ada beberapa faktor yang perlu diperhatikan, karena sangat menentukan dan berperan dalam proses pembelajaran, yaitu.

a. pendidik atau guru

b. peserta didik

c. tujuan pendidikan

d. alat pendidikan (prangkat lunak \& prangkat keras)

e. lingkungan pendidikan.

\section{Faktor Pendidik atau Guru}

Menurut Wina Sanjaya, ${ }^{22}$ dalam implementasi suatu strategi pembelajaran, faktor guru sangatlah menentukan. Tanpa guru, bagaimanapun idealnya suatu strategi pembelajaran, tidak mungkin dapat dilaksanakan. Keberhasilan implementasi suatu strategi pembelajaran akan tergantung pada kepiawaian guru dalam menggunakan metode dan teknik pembelajaran. Setiap guru tentu mempunyai pengalaman, kemampuan, gaya, dan bahkan pandangan yang berbeda dalam mengajar. Ada yang memandang, mengajar hanya sebatas menyampaikan materi pelajaran. Akan tetapi, ada 
juga yang memandang, mengajar adalah suatu proses pemberian bantuan kepada peserta didik untuk mengembangkan kepribadiannya.

Peran guru tidak dapat digantikan oleh perangkat atau teknologi pembelajaran apapun, misalnya televisi, tape recorder, dan sebagainya. Sebabnya, karena siswa atau peserta didik adalah organisme yang sedang berkembang yang memerlukan bimbingan dan bantuan orang dewasa atau guru. Dalam proses pembelajaran, seorang guru tidak hanya berperan sebagai teladan pada siswa yang diajarnya, tetapi juga sebagai pengelola pembelajaran (manager of learning). Dengan demikian, efektivitas proses pembelajaran terletak pada guru. Oleh karena itu, keberhasilan suatu proses pembelajaran sangat ditentukan oleh kualitas atau kemampuan guru.

Ada beberapa aspek yang dapat mempengaruhi kualitas proses pembelajaran dilihat dari faktor guru. Aspek tersebut meliputi jenis kelamin, pengalaman dan latar belakang sosial guru (asal, suku, adatistiadat/budaya, keadaan keluarga/harmonis atau tidak, berkemampuan atau tidak, dan semacamnya). Aspek lain yang berpengaruh adalah pengalaman mengajar dan latar belakang pendidikan guru. Juga sifat-sifat yang dimiliki seorang guru, misalnya: sikap guru terhadap profesinya, sikap guru terhadap siswa, kemampuan atau inteligensi guru, kemampuan mengelola pembelajaran (perencanaan, penguasaan materi, dan evaluasi).

\section{Faktor Peserta Didik atau Siswa}

Peserta didik adalah organisme atau individu yang unik, pertumbuhan jasmani dan perkembangan rohaninya mengikuti tahap-tahap perkembangannya. Tempo dan irama perkembangan masing-masing anak pada setiap aspek tidak selamanya sama. Proses pembelajaran dapat dipengaruhi oleh perkembangan anak yang tidak sama itu, selain karakteristik bawaan atau bakat pada masing-masing anak yang kadangkala berbeda pula.

Ada beberapa aspek yang dapat mempengaruhi proses pembelajaran dilihat dari faktor peserta didik/siswa. Antara lain, aspek lingkungan dan tempat tinggal siswa, latar belakang keluarga, dan tingkat sosial ekonomi peserta didik/siswa. Selain itu, kemampuan dasar dan sikap peserta didik/siswa dapat pula berpengaruh. Setiap peserta didik/siswa mempunyai kemampuan yang berbeda. Ada yang kemampuannya tinggi, sedang, dan rendah. Pada umumnya terdapat hubungan yang linear antara kemampuan dan sikap serta motivasi belajar peserta didik/siswa. Semakin tinggi kemampuan siswa, semakin tinggi pula motivasi belajar, perhatian, 
dan keseriusan mengikuti pelajaran. Artinya, peserta didik/siswa yang kemampuannya rendah, terjadi sebaliknya. Itulah sebabnya sehingga di dalam proses pembelajaran, peserta didik menjadi salah satu faktor yang dapat menentukan berhasil tidaknya suatu pendidikan.

\section{Faktor Tujuan Pendidikan}

Tujuan pendidikan ataupun tujuan pembelajaran menjadi arah setiap proses pembelajaran. Setiap instrumen yang digunakan dalam pembelajaran, harus mendukung ke arah tercapainya tujuan yang ingin dicapai. Tentu saja di dalam menetapkan atau merumuskan suatu tujuan pendidikan, sangat terkait dengan faktor perkembangan peserta didik. Setiap lembaga penyelenggara atau satuan pendidikan, dituntut menetapkan visi, misi, dan tujuan pendidikannya, baik tujuan umum, tujuan sementara, maupun tujuan akhirnya, karena tujuan tersebut menjadi salah satu faktor penting dan sangat menentukan di dalam pendidikan.

\section{Faktor Alat Pendidikan (Sarana-prasarana)}

Sarana pembelajaran adalah segala sesuatu yang mendukung secara langsung terlaksana dan lancarnya proses pembelajaran. Kurikulum, laboratorium, perpustakaan, media dan teknologi pembelajaran, serta alat pembelajaran lainnya (gedung, ruangan kelas dan segala kelengkapannya), adalah tergolong sarana pembelajaran. Prasarana pembelajaran adalah segala sesuatu yang secara tidak langsung dapat mendukung keberhasilan proses pembelajaran. Jalanan menuju sekolah, penerangan sekolah, kamar mandi, dan semacamnya, adalah tergolong prasarana pembelajaran.

Kelengkapan alat pendidikan akan membantu guru dan siswa dalam penyelenggaraan proses pembelajaran. Dengan demikian, sarana dan prasarana pendidikan merupakan komponen penting yang dapat mempengaruhi proses pembelajaran.

Semakin lengkap alat pendidikan akan semakin tumbuh gairah dan motivasi guru mengajar dan siswa belajar. Dengan lengkapnya alat, guru dapat menggunakan alat pembelajaran yang mendukung keberhasilan siswa yang mempunyai tipe belajar visual, auditif, dan psikomotorik.

\section{Faktor Lingkungan Pendidikan}

Ada dua faktor lingkungan yang sangat berpengaruh dalam proses pembelajaran; yaitu faktor organisasi kelas dan faktor iklim sosialpsikologis.

Faktor organisasi kelas, yang di dalamnya meliputi jumlah siswa dalam satu kelas, merupakan aspek penting yang dapat mempengaruhi 
berhasil tidaknya proses pembelajaran. Organisasi kelas yang terlalu besar akan kurang efektif untuk mencapai tujuan pembelajaran. Artinya, jumlah anggota kelompok besar akan kurang menguntungkan dalam menciptakan iklim belajar-mengajar yang kondusif.

Faktor iklim sosial-psikologis dapat pula menentukan tercapainya tujuan pendidikan. Keharmonisan hubungan antar orang yang terlibat dalam proses pembelajaran akan sangat mempenagruhi pelaksanaan pendidikan.

Iklim sosial-psikologis ini dapat terjadi secara internal maupun eksternal. Secara internal adalah hubungan antara orang yang terlibat dalam lingkungan sekolah. Hubungan antara siswa dengan siswa, siswa dengan guru, guru dengan guru, guru dengan pimpinan, guru dengan karyawan, karyawan dengan karyawan, dan karyawan dengan atasan. Terjalinkah hubungan sosial yang harmonis dan terbangunkah hubungan psikologis yang mendalam di antara mereka?

Secara eksternal adalah keharmonisan hubungan antara pihak sekolah dengan dunia luar. Hubungan sekolah dengan orang tua siswa, hubungan sekolah dengan lembaga-lembaga masyarakat, hubungan sekolah dengan masyarakat sekitarnya, dan semacamnya. Terbangunkah iklim yang kondusif antara sekolah dengan lingkungannya?

Menurut Wina Sanjaya, ${ }^{23}$ dan mungkin juga sudah menjadi pendapat umum, bahwa sekolah yang mempunyai hubungan baik secara internal yang ditunjukkan dengan kerja sama antar guru, pimpinan, karyawan, dan peserta didik, saling menghargai dan saling membantu, maka iklim belajar dan mengajar menjadi sejuk dan tenang, sehingga akan berdampak pada motivasi mengajar pada guru dan motivasi belajar pada siswa. Sebaliknya, hubungan internal yang tidak harmonis akan menyebabkan iklim belajar penuh dengan ketegangan dan ketidaknyamanan, sehingga tentu saja akan mempengaruhi psikologi siswa dalam belajar dan guru dalam mengajar. Demikian pula sekolah yang mempunyai hubungan harmonis dengan lembaga-lembaga luar, akan menambah kelancaran program sekolah, sehingga upaya-upaya sekolah dalam meningkatkan kualitas pembelajaran akan mendapat dukungan dari pihak lain.

\section{PANDANGAN TENTANG KEWAJIBAN DAN HAK GURU}

Salah satu faktor yang sangat urgen dari lahirnya Undang-undang RI Nomor: 14 Tahun 2005 tentang Guru dan Dosen adalah kepastian jaminan hak dan kewajiban guru dan dosen. Menurut Trianto dan Titik, ${ }^{24}$ sudah selayaknya guru sebagai pekerja profesi mendapat kepastian jaminan hak dan kewajiban serta legitimasi keprofesiannya. Menurutnya, kewajiban 
guru merujuk segala apa yang harus dilakukan oleh guru, termasuk tugas pengetahuan dan kemampuan profesional, personal, dan sosial. Sedangkan hak, merujuk pada apa yang seharusnya didapatkan dari yang telah dilakukan (kewajiban), sehingga antara hak dan kewajiban harus sinergis, seimbang, dan konstruktif.

\section{Kewajiban guru}

\section{Mengajar dan Mendidik}

Beberapa pandangan ahli mengakui bahwa manusia perlu dididik karena mempunyai potensi untuk berkembang yang dibawa sejak lahir. Kalau potensi tersebut tidak dibina dan diarahkan (tidak dididik), maka ia akan berkembang salah ke arah yang negatif. Di dalam Alquran, potensi perkembangan manusia yang dibawa sejak lahir dikenal dengan "fithrah." Baca Q.S. Ar-Ruum (30): 30, yang artinya: "maka hadapkanlah wajahmu dengan lurus kepada agama (Allah); (tetaplah) atas fithrah Allah yang telah menciptakan manusia menurut fithrah itu. Tidak ada perubahan pada fithrah Allah, (itulah) agama yang lurus; tetapi kebanyakan manusia tidak mengetahui." 25 Dapat juga dilihat Hadis yang diriwayatkan Imam Bukhari, yang artinya: "setiap manusia yang lahir, ia lahir dengan fithrahnya (potensi kebaikan untuk berkembang), maka orang tuanyalah (lingkungannya) yang dapat menjadikannya beragama Yahudi, Nasrani, maupun Majusi."

Dalam hubungannya dengan proses pembelajaran dapat pula dibaca, Q.S. An-Nahl (16): 78, yang artinya: “Dan Allah mengeluarkan kamu (manusia) dari perut ibumu dalam keadaan tidak mengetahui sesuatu apapun. Dan Dia (Allah) memberi kamu pendengaran, penglihatan, dan hati, agar kamu bersyukur." Oleh karena itu, dapat dipahami, bahwa guru sebagai penanggung jawab pendidikan formal, berkewajiban mengembangkan potensi dasar manusia atau peserta didik ke arah yang positif supaya tidak berkembang salah.

\section{Guru sebagai Pengajar}

Sebagai pengajar, guru berkewajiban membantu peserta didik yang sedang berkembang untuk mempelajari sesuatu yang belum diketahuinya, membentuk kompetensi, dan memahami materi standar yang dipelajari. ${ }^{26}$ Ini berarti bahwa sebagai pengajar, guru hanya dituntut untuk memberikan pelajaran kepada peserta didik supaya mereka cerdas dan dapat memahami pelajaran yang diberikan. Artinya, sebagai tugas pengajar, yang diutamakan adalah membina kecerdasan intelektual peserta didik. 


\section{Guru sebagai Pendidik}

Meskipun pada bagian pendahuluan sudah dikemukakan pengertian guru, tetapi ada baiknya dalam pembahasan ini dikemukakan apa yang dimaksud dengan guru sebagai pendidik. Untuk itu, perlu diketahui apa arti kata "guru" dan apa pula arti kata "pendidik."

Dalam Kamus Besar Bahasa Indonesia (KBBI) disebutkan bahwa guru adalah orang yang pekerjaannya (mata pencahariannya, profesinya) mengajar. ${ }^{27}$ Kata "mengajar" mengandung arti memberi pelajaran, tetapi dapat pula berarti melatih. Sedangkan kata "pendidik" menurut W.J.S. Poerwadarminta adalah orang yang mendidik atau yang memelihara serta memberi latihan mengenai budi pekerti atau akhlak dan kecerdasan pikiran. ${ }^{28}$

Sebagai pendidik, guru adalah tokoh, panutan para peserta didik dan lingkungannya. Oleh karena itu, guru dituntut untuk memiliki standar kualitas pribadi tertentu, yang mencakup tanggung jawab, wibawa, kemandirian, disiplin, dan kompetensi serta profesionalisme. Pada guru dituntut tanggung jawab dan kepribadian yang utuh. Menurut Zakiah Daradjat, kepribadian itulah yang akan menentukan apakah ia menjadi pendidik dan pembina yang baik bagi anak didiknya, ataukah akan menjadi perusak bagi hari depan anak didik (terutama pada tingkat dasar) dan mereka yang sedang mengalami kegoncangan jiwa (peserta didik tingkat sekolah menengah). ${ }^{29}$

Berkaitan dengan tanggung jawab, menurut pandangan penulis, guru harus mengetahui serta memahami nilai budaya, norma agama, serta berusaha berperilaku dan berbuat sesuai nilai budaya dan norma agama yang berakar kuat di masyarakat. Guru harus bertanggung jawab melaksanakan pembelajaran untuk mengembangkan peserta didik menjadi cerdas dan sekaligus berbudi pekerti luhur sesuai dengan nilai budaya dan norma agama yang berkembang di masyarakat.

Dengan demikian, guru sebagai pendidik berarti bahwa selain mengajar, ia juga mendidik anak menjadi berbudi pekerti luhur. Artinya, selain membina kecerdasan intektual anak, ia juga membina kecerdasan emosional, kecerdasan spiritual, dan kecerdasan sosial peserta didik. Oleh karena itu, seorang guru harus melaksanakan tugasnya secara profesional

dan mesti memiliki kompetensi pedagogik, kompetensi kepribadian, dan kompetensi sosial.

Kompetensi pedagogik guru, sekurang-kurangnya meliputi; pemahaman wawasan atau landasan kependidikan, pemahaman terhadap peserta didik, pengembangan kurikulum atau silabus, perancangan pem- 
belajaran yang mendidik dan dialogis, memanfaatkan teknologi pembelajaran, evaluasi hasil belajar, dan pengembangan peserta didik untuk mengaktualisasikan berbagai potensi yang dimilkinya.

Kompetensi kepribadian guru, sekurang-kurangnya harus meliputi: mantap, stabil emosi, dewasa, arif dan bijaksana, berwibawa, berakhlak mulia, menjadi teladan bagi peserta didik dan masyarakat, secara obyektif mengevaluasi kinerja sendiri, dan mengembangkan diri secara mandiri dan berkelanjutan.

Kompetensi sosial guru, sekurang-kurangnya meliputi: kompetensi berkomunikasi lisan, tulisan, dan atau isyarat, menggunakan teknologi komunikasi dan informasi secara fungsional, bergaul secara efektif dengan peserta didik, sesama pendidik, tenaga kependidikan, orang tua/wali peserta didik, dan bergaul secara santun dengan masyarakat sekitar.

Kompetensi profesional guru merupakan kemampuan penguasaan materi pelajaran secara luas dan mendalam dalam melaksanakan tugas yang sungguh-sungguh, teliti, dan bertanggung jawab.

Dari uraian di atas, saya berpandangan, bahwa dalam proses pembelajaran, guru dituntut kemampuannya untuk mengembangkan potensi peserta didik sehingga terjadi perubahan pada peserta didik tersebut. Perubahan yang dimaksud adalah perubahan sikap dan perilaku serta yang lainnya ke arah yang lebih positif. Misalnya, perubahan dari tidak berilmu menjadi berilmu, dari tidak etis menjadi etis, dan dari malas menjadi rajin.

Dengan keterangan di atas, saya berkesimpulan, bahwa inti atau hakekat dari pendidikan atau proses pembelajaran adalah "perubahan". Sedangkan inti atau hakekat dari ilmu pengetahuan adalah "manfaat". Sekecil atau sesedikit apapun ilmu yang dimiliki, tetapi ia bermanfaat, maka itu jauh lebih berharga dan lebih mulia dari ilmu yang banyak, tetapi tidak bermanfaat. Ilmu yang tidak diamalkan/tidak bermanfaat, laksana pohon yang tidak berbuah/tidak berguna.

\section{Hak Guru}

1. Mendapatkan jaminan kesejahteraan lahir-batin (kesejahteraan lahir, meliputi gaji dan tunjangan lain yang memadai. Kesejahteraan batin, meliputi penghargaan pemerintah, orang tua anak didik, masyarakat, dan anak didik sendiri)

2. Mendapat perlindungan dan kepastian hukum

3. Menggunakan fasilitas pembelajaran yang memadai

4. Mendapatkan iklim kerja yang kondusif (ruangan istirahat, ruangan kelas yang sejuk dan representatif) 
5. Mendapat kepastian dan jaminan jenjang karir

6. Dapat menyalurkan aspirasi secara bebas, tetapi bertanggung jawab melalui lembaga resmi atau organisasi profesi keguruan, semisal Persatuan Guru Republik Indonesia (PGRI). ${ }^{30}$

\section{PENUTUP}

Dari uraian di atas, ada beberapa kesimpulan yang dapat dikemukakan berikut ini.

1. Hakekat atau inti dari pendidikan adalah perubahan untuk maju. Sedangkan hakekat atau inti dari ilmu pengetahuan adalah manfaat.

2. Guru sangat dibutuhkan oleh setiap orang di setiap bangsa di dunia ini. Guru yang berkualitas tinggi dan sejahtera akan dapat bekerja secara profesional.

3. Kurikulum, laboratorium, sarana-prasarana pendidikan yang maju, tidak akan berarti tanpa digunakan oleh guru yang bekompeten.

4. Guru adalah unsur utama dalam keseluruhan proses pembelajaran. Tanpa guru, pendidikan hanya akan menjadi pembicaraan yang omong kosong.

5. Guru sebagai pendidik adalah orang yang pekerjaannya mengajar, mendidik, dan melatih peserta didik dengan tujuan agar peserta didik tersebut dapat memiliki ilmu pengetahuan, keterampilan, budi pekerti atau akhlak mulia, dan bisa berpikir secara cerdas dan rasional.

6. Tipologi guru sebagai pendidik tercermin pada sejumlah syarat yang harus dimiliki oleh seorang guru, pada sifat-sifat yang harus melekat pada dirinya. Juga melekat pada tugas pokoknya sebagai pengajar, pendidik, dan pelatih peserta didik.

7. Multi peran guru sangat kompleks dan tidak hanya dimainkan di sekolah, tetapi juga di luar sekolah. Di sekolah, guru selain berperan sebagai pengajar, pendidik, dan pelatih peserta didik, ia juga berperan sebagai motivator, mediator, fasilitator, evaluator, dan pengelola kelas. Sedangkan di luar sekolah, guru berperan sebagai pengayom dan teladan di lingkungan keluarga dan di dalam kehidupan masyarakat.

\section{CATATAN AKHIR:}

1. Abuddin Nata, Tafsir Ayat-ayat Pendidikan, Jakarta: Raja Grafindo Persada, 2002, h. 37.

2. Departemen Agama RI, Alquran dan Terjemahnya, Saudi Arabia: Majma' AlMalik Fahd, 1422 H., h. 910. Baca juga Zakiah Daradjat, Ilmu Pendidikan Islam, Jakarta: Bumi Aksara, 1996, h. 7. 
3. Muhammad Athiyah Al-Abrasyi, Ruh Al-Islam, Mathba' ah Lajnah Al-Bayan Al'Arabi, 1964. Terjemahan oleh Syamsuddin Asyrofi, Achmad Warid Khan, dan Nizar Ali, Beberapa Pemikiran Pendidikan Islam, Yogyakarta: Titian Ilahi Press, 1996.

4. Bahaking Rama, Jejak Pembaharuan Pendidikan Pesantren, Jakarta: Paradotama Wiragemilang, 2003, h. 29.

5. Departemen Agama RI, Alquran dan Terjemahnya, h. 116.

6. Muhamad Surya, Percikan Perjuangan Guru, Semarang: Aneka Ilmu, 2003, h. 2.

7. Tim Pustaka Merah Putih, Undang-Undang Sistem Pendidikan Nasional, Guru dan Dosen, Yogyakarta: Pustaka Merah Putih, 2007, h. 85.

8. Syaiful Bahri Djamarah, Guru dan Anak Didik dalam Interaksi Edukatif, Jakarta: Rineka Cipta, 200, h. 31.

9. Zakiah Daradjat, Ilmu Pendidikan Islam, Jakarta: Bumi Aksara, 1996, h. 39.

10. Muhamad Surya, Percikan Perjuangan Guru, h. 335.

11. Di dalam UURI Nomor: 14 Tahun 2005 tentang Guru dan Dosen dijelaskan bahwa profesional adalah pekerjaan atau kegiatan yang dilakukan oleh seseorang dan menjadi sumber penghasilan kehidupan yang memerlukan keahlian, kemahiran, atau kecakapan yang memenuhi standar mutu atau norma tertentu serta memerlukan pendidikan profesi. Baca, Tim Pustaka Merah Putih, Undang-Undang Sistem Pendidikan Nasional, Guru dan Dosen, h. 85.

12. Martinis Yamin, Profesionalisme Guru dan Implementasi KTSP, Jakarta: Gaung Persada Press, 2007, h. 4.

13. Baca Ace Suryadi dan Dasim Budimansyah, Pendidikan Nasional Menuju Masyarakat Indonesia Baru, PT. Genesindo, Bandung, 2004, h. 177. Baca juga Ace Suryadi, Pendidikan Investasi Sumber daya Manusia dan Pembangunan, Jakarta: Balai Pustaka, 1999, h. 303. Baca juga, Onny S. Prijono dan Pranarka, Situasi Pendidikan di Indonesia Selama Sepuluh Tahun Terakhir, Jakarta: Yayasan Proklamasi, 1979, h. 111.

14. Muhamad Surya, Percikan Perjuangan Guru, h. 341.

15. Muhammad Athiyah Al-Abrasyi, Beberapa Pemikiran Pendidikan Islam, h. 66.

16. Indra Djati Sidi, Menuju Masyarakat Belajar, Jakarta: Paramadina dan Logos, 2001, h. 38. Baca juga H. Tarsa, Basic Kompetensi Guru, Jakarta: Depag RI, 2003, h. 5.

17. Soedijarto, Pendidikan sebagai Sarana Reformasi Mental dalam Upaya Pembangunan Bangsa, Jakarta: Balai Pustaka, 1998, h. 79.

18. Muhamad Surya, Percikan Perjuangan Guru, h. 342.

19. Zakiah Daradjat, Ilmu Pendidikan Islam, h. 41.

20. Muhammad Athiyah Al-Abrasyi, Ruh Al-Islam, h. 66.

21. Departemen Pendidikan Nasional, Undang-undang RI. Nomor: 20 Tahun 2003 tentang Sistem Pendidikan Nasional beserta Penjelasannya, Bandung: Fokusmedia, 2003, h. 7.

22. Wina Sanjaya, Strategi Pembelajaran, Jakarta: Kencana, 2007, h. 50.

23. Wina Sanjaya, Strategi Pembelajaran, h. 55.

24. Trianto dan Titik Triwulan Tutik, Sertifikasi Guru dan Upaya Peningkatan Kualifikasi, Kompetensi, dan Kesejahteraan, Jakarta: Prestasi Pustaka, 2007, h. 5.

25. Departemen Agama RI, Alquran dan Terjemahnya, h. 645. 
26. E. Mulyasa, Menjadi Guru Profesional, Bandung: Remaja Rosda Karya, 2005, h. 38.

27. Tim Redaksi KBBI, Kamus Besar Bahasa Indonesia, edisi ketiga, cet. I, Jakarta: Balai Pustaka, 2001, h. 377.

28. W.J.S. Poerwadarminta, Kamus Umum Bahasa Indonesia, cet. VIII, Jakarta: Balai Pustaka, 1985, h. 250.

29. Zakiyah Daradjat, Kepribadian Guru, Jakarta: Bulan Bintang, 2005, h. 9.

30. Organisasi profesi keguruan (PGRI) harus bersifat otonom dan tidak diintervensi oleh kepentingan birokrasi. Organisasi ini perlu mengkaji tentang guru dan segala sangkut paut kepentingan guru. Masalah apa yang dihadapi guru sehingga mutu pendidikan rendah, dan kajian lain yang semacamnya.

\section{DAFTAR PUSTAKA:}

Al-Abrasyi, Muhammad Athiyah, Ruh Al-Islam, Mathba'ah Lajnah Al-Bayan Al'Arabi, 1964. Terjemahan oleh Syamsuddin Asyrofi, Achmad Warid Khan, dan Nizar Ali, Beberapa Pemikiran Pendidikan Islam, Yogyakarta: Titian Ilahi Press, 1996.

Daradjat, Zakiah, Ilmu Pendidikan Islam, Jakarta: Bumi Aksara, 1996.

Departemen Agama RI, Alquran dan Terjemahnya, Saudi Arabia: Majma' Al-Malik Fahd, 1422 H.

Departemen Pendidikan Nasional, Undang-undang RI Nomor: 20 Tahun 2003 tentang Sistem Pendidikan Nasional beserta Penjelasannya, Bandung: Fokusmedia, 2003.

Djamarah, Syaiful Bahri, Guru dan Anak Didik dalam Interaksi Edukatif, Jakarta: Rineka Cipta, 200.

Mulyasa, E., Menjadi Guru Profesional, Bandung: Remaja Rosda Karya, 2005.

Nata, Abuddin, Tafsir Ayat-ayat Pendidikan, Jakarta: Raja Grafindo Persada, 2002.

Poerwadarminta, W.J.S., Kamus Umum Bahasa Indonesia, cet. VIII, Jakarta: Balai Pustaka, 1985.

Prijono, Onny S. dan Pranarka, Situasi Pendidikan di Indonesia Selama Sepuluh Tahun Terakhir, Jakarta: Yayasan Proklamasi, 1979.

Rama, Bahaking, Jejak Pembaharuan Pendidikan Pesantren, Jakarta: Paradotama Wiragemilang, 2003.

Sanjaya, Wina, Strategi Pembelajaran, Jakarta: Kencana, 2007.

Sidi, Indra Djati, Menuju Masyarakat Belajar, Jakarta: Paramadina dan Logos, 2001.

Soedijarto, Pendidikan sebagai Sarana Reformasi Mental dalam Upaya Pembangunan Bangsa, Jakarta: Balai Pustaka, 1998.

Surya, Muhamad, Percikan Perjuangan Guru, Semarang: Aneka Ilmu, 2003.

Suryadi, Ace dan Dasim Budimansyah, Pendidikan Nasional Menuju Masyarakat Indonesia Baru, PT. Genesindo, Bandung, 2004.

Suryadi, Ace, Pendidikan Investasi Sumber daya Manusia dan Pembangunan, Jakarta: Balai Pustaka, 1999.

Tarsa, H., Basic Kompetensi Guru, Jakarta: Depag RI, 2003.

Tim Pustaka Merah Putih, Undang-undang Sistem Pendidikan Nasional, Guru dan Dosen, Yogyakarta: Pustaka Merah Putih, 2007. 
Tim Redaksi KBBI, Kamus Besar Bahasa Indonesia, edisi ketiga, cet. I, Jakarta: Balai Pustaka, 2001.

Trianto dan Titik Triwulan Tutik, Sertifikasi Guru dan Upaya Peningkatan Kualifikasi, Kompetensi, dan Kesejahteraan, Jakarta: Prestasi Pustaka, 2007.

Yamin, Martinis, Profesionalisme Guru dan Implementasi KTSP, Jakarta: Gaung Persada Press, 2007. 